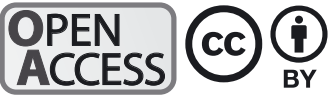

\section{Chemicals used for maintenance of wood rafts in mussel farms: evaluation of their potential toxic risk to mussel culture}

\author{
Y. Ruiz ${ }^{1}$, P. Suárez ${ }^{1}$, A. Alonso ${ }^{1}$, E. Longo ${ }^{2}$, F. San Juan ${ }^{1, *}$ \\ ${ }^{1}$ Department of Biochemistry, Genetics and Immunology, Faculty of Marine Sciences, University of Vigo, \\ Lagoas-Marcosende s/n, 36310 Vigo, Spain \\ ${ }^{2}$ Department of Functional Biology and Health Sciences, Faculty of Biology, University of Vigo, Lagoas-Marcosende s/n, \\ 36310 Vigo, Spain
}

\begin{abstract}
At the Galician coast, mussels are cultured on vertical ropes attached to floating rafts, which are cleaned in situ with tars or waterproof paints. The present study analyses the composition and the toxic risk of several compounds used during maintenance, in order to improve mussel-farming practices. The toxic risk was determined in relation to that of benzo(a)pyrene (BaP) by calculating the carcinogenic toxic equivalency (TEQ) and evaluating the mutagenic potential using a mutagenicity test based on Vibrio harveyi. The greatest toxic risk was determined for a random mixture of petroleum tars and diesel combusted oil (MTO). This mixture showed a concentration of polycyclic aromatic hydrocarbons 200 -fold higher than that of coal tar (CT) and 256-fold higher than pine tar (PT) as well as significantly higher concentrations of $\mathrm{Pb}$ and Mn. The TEQ value of MTO was 581-fold and 486-fold higher than that of the CT and PT, respectively. In the waterproof paint (WP) analysed, hydrocarbons were not detected, but the $\mathrm{Mn}, \mathrm{Cr}$, $\mathrm{Cu}, \mathrm{Sn}$, and Ni content of the WP was significantly higher than that of the tars. Mutagenicity of the tars was dose-dependent and increased after metabolic activation. The MTO showed mutagenic effects that were significantly higher than those of CT and PT but still less than expected, suggesting that the mutagenic potential of all 3 mixtures depends on their concentration and composition, which determine their solubility and biodegradability. The WP did not show mutagenic effects. Our results suggest that the use of WP and PT is more suitable for the maintenance of rafts and could reduce the pollutant impact in the mussel farms.
\end{abstract}

KEY WORDS: Mussel farms · Chemical pollution · Mutagenicity · Vibrio harveyi test

\section{INTRODUCTION}

Galician Rías (NW Spain) are one of the largest productive areas of mussels in the world (SánchezMata \& Mora 2000, Caballero Miguez et al. 2009). The culture is carried out in floating rafts made with beams of eucalyptus wood supporting submerged cords, to which mussels attach and grow (Fig. 1). The raft maintenance and cleaning is usually performed in situ with tars or waterproof paints. Mussels, as filtering organisms, ingest particulate and dissolved

${ }^{*}$ Corresponding author: fsanjuan@uvigo.es forms of pollutants along with food, concentrating these pollutants to levels well above those in the surrounding seawater (Baumard et al. 1999). Therefore, the spillage of these substances around rafts entails a direct pollution risk on the immediate environment and the mussel culture itself, which can affect not only the quality of the product but also food safety if these chemicals are accumulated above the recommended values for human consumption (WHO 1991). Thus, it seems necessary to evaluate the toxicity of these compounds.

(C) The authors 2014. Open Access under Creative Commons by Attribution Licence. Use, distribution and reproduction are unrestricted. Authors and original publication must be credited. 


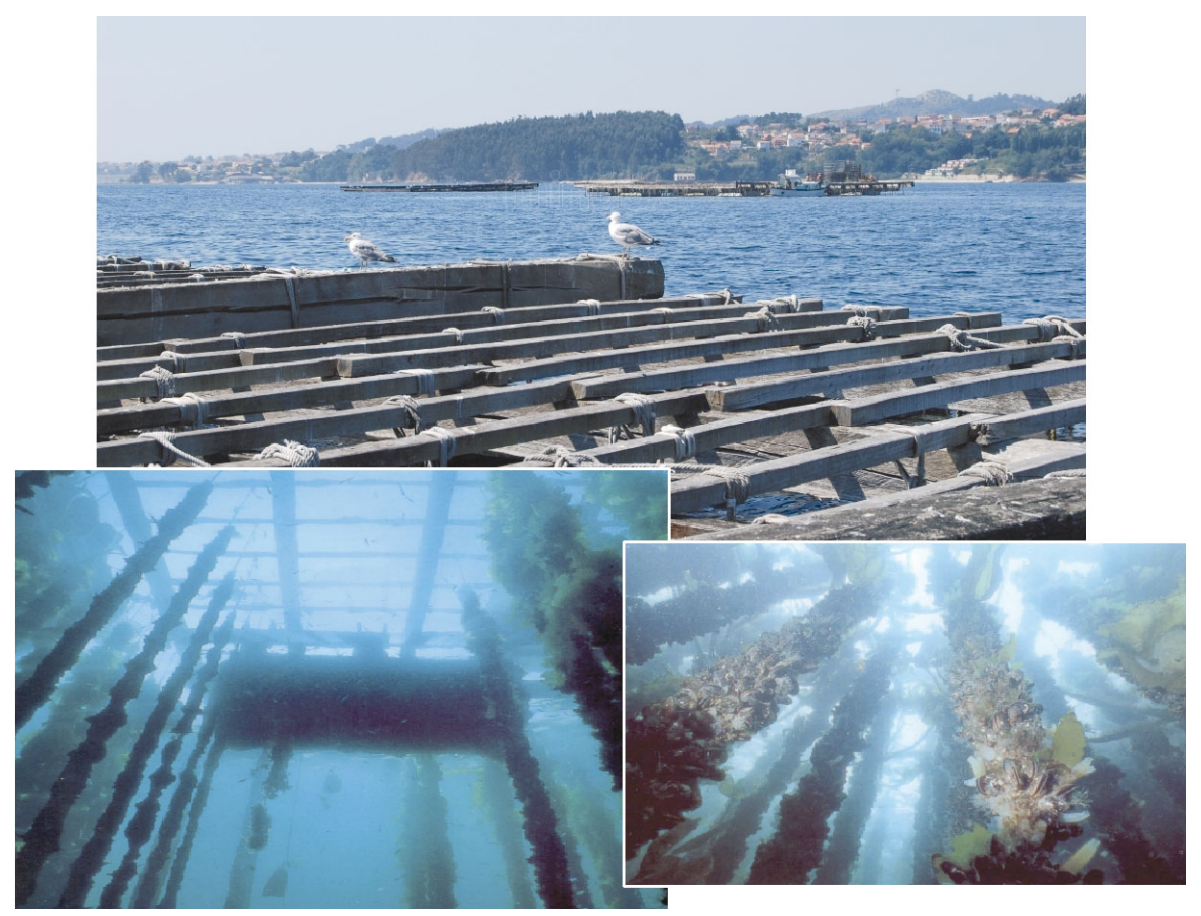

Fig. 1. Wooden floating rafts in the mussel farms from the Ría of Vigo. (Images from Durán Neira et al. 1990)

The compounds described are complex mixtures whose toxicological evaluation is difficult due to interactions of chemical, physical and physiological factors. Only their soluble or dispersed fraction in the water column is bioavailable and can be accumulated in marine organisms, exerting its toxic effect (McElroy et al. 1989). One of the most harmful effects of most toxic pollutants is mutagenicity, which has been related to carcinogenesis (Mortelmans \& Zeiger 2000, Barton et al. 2005). Although toxicity is a broad concept that includes many other harmful effects, all compounds inducing mutagenesis or carcinogenesis are considered toxic. This consideration justifies that mutagenicity and carcinogenicity have been widely accepted for assessing the toxicity of chemicals. Based on these 2 effects, several authors have established toxic equivalency factors for each individual polycyclic aromatic hydrocarbon (PAH) relative to Benzo(a)pyrene, which is the most toxic PAH (Nisbet \& La Goy 1992, US EPA 1993, Villeneuve et al. 2002). The toxic equivalency of a mixture can be calculated from these factors. However, this method does not consider physical or physiological interactions that may attenuate or enhance the mixture's toxicity. Therefore, in vivo assays, such as mutagenicity tests, would better reflect a mixture's actual toxicity.

The most commonly used mutagenicity test for the analysis of chemical compounds with legal recognition is the one described by Ames using genetically modified strains of Salmonella typhimurium (Ames 1971, Ames et al. 1975, Maron \& Ames 1983, Mortelmans \& Zeiger 2000). However, this bacterium has low survival in the presence of salts, so marine bacteria adapted to high osmotic pressures seem more suitable to evaluate chemical toxicity in marine environments (Czyz et al. 2002, Wegrzyn \& Czyz 2003, Ohe et al. 2004, Podgórska \& Wegrzyn 2007, Chec et al. 2008). For this reason, other mutagenicity assays using marine bacteria have been developed, such as the one based upon detection of neomycin-resistant mutants of Vibrio harveyi. The effectiveness of this assay has been compared to the Ames test, showing the highest sensitivity in samples with sea water (Czyz et al. 2000, 2002, 2003, Słoczynska et al. 2010, Ruiz et al. 2013).

Biodegradation of toxic compounds by living organisms is conducted by microsomal enzymes that are NAD(P)H-dependent (reductases and cytochromes P450), which produce compounds that are more soluble and easy to remove. However, these products are often more toxic than the parent compounds, resulting in a metabolic activation or bioactivation of toxicity (Lehr \& Jerina 1977, Stegeman 1981, López-Barea \& Pueyo 1998). Therefore, the mutagenic ability of the metabolic products of these compounds would indicate the real toxic potential of the compounds for organisms. 
A direct relationship among seawater mutagenicity from aquaculture farms, accumulation of high concentrations of pollutants in cultured mussels and development of gonadal neoplasias in these organisms has been shown by our group in previous papers focused in the Ría of Vigo (Ruiz et al. 2011, 2013). The present work is a study of the composition and toxic risk of 4 compounds generally used in maintenance and cleaning of floating rafts in order to identify their pollutant contribution in aquaculture areas and improve mussel farming practices, ensuring their sustainability as well as the product quality and consumer safety.

\section{MATERIALS AND METHODS}

\section{Composition of chemical compounds}

Four compounds generally used in cleaning and maintenance of mussel rafts were provided by mussel farmers from the Ría of Vigo. These were a random mixture of petroleum tars and diesel combusted oil (MTO); a commercial coal tar (CT); tar of pine wood (PT); and a waterproof paint (WP). Their compositions in hydrocarbons and heavy metals were analysed.

The analyses of the levels of PAHs and trace metals were contracted to the Spanish Institute of Oceanography (IEO, Centre of Vigo) and the Centre for Scientific and Technological Support to Research (CACTI) of the University of Vigo, respectively. PAHs were extracted using a Soxhlet system with a hexane:acetone mixture (3:1 v/v). The PAHs were separated and quantified by high-performance liquid chromatography (HPLC) with fluorimetric detection. A total of 13 PAHs were measured: phenanthrene (Phe), anthracene (An), fluoranthene (Flt), pyrene (Py), benzo(a)anthracene (BaA), chrysene (Chry), benzo(b)fluoranthene (BbF), benzo(k)fluoranthene $(\mathrm{BkF})$, benzo(e)pyrene $(\mathrm{BeP})$, benzo(a)pyrene (BaP), dibenzo(a,h) anthracene (DBA), benzo( $g, h, i)$ perylene (Bper), and indeno$(1,2,3,-\mathrm{c}, \mathrm{d})$ pyrene (IP). Trace metals were determined by optical emission spectroscopy with inductively coupled plasma as the excitation source (ICP-OES) after a hydrogen peroxide:nitric acid (2:5) digestion. The Hg level was determined by cold vapor atomic absorption spectrometry. A total of 11 trace elements were measured: As, Cd, Cr, $\mathrm{Cu}, \mathrm{Mn}, \mathrm{Ni}, \mathrm{Pb}, \mathrm{V}, \mathrm{Zn}, \mathrm{Hg}$, and $\mathrm{Sn}$. All analyses were performed in triplicate, and the results were expressed as $\mathrm{mg} \mathrm{kg}^{-1}$ dry weight (dw).
Table 1. Toxic equivalency factors (TEFs) of PAHs. TEF values for each hydrocarbon species compared to the toxicity of BaP (Nisbet \& La Goy 1992, US EPA 1993)

\begin{tabular}{|ll|}
\hline Compound & TEF \\
\hline Phenanthren (Phe) & 0.001 \\
Anthracene (An) & 0.01 \\
Fluoranthene (Flt) & 0.001 \\
Pyrene (Py) & 0.001 \\
Benzo(a)anthracene (BaA) & 0.1 \\
Chrysene (Chry) & 0.01 \\
Benzo(b)fluoranthene (BbF) & 0.1 \\
Benzo(k)fluoranthene (BkF) & 0.1 \\
Benzo(a)pyrene (BaP) & 1 \\
Dibenzo(a,h)anthracene (DBA) & 1 \\
Benzo(g,h,i)perylene (Bper) & 0.01 \\
Indeno(1,2,3,-c,d)pyrene (IP) & 0.1 \\
\hline
\end{tabular}

\section{Toxic equivalency}

The toxic equivalency (TEQ) of the 4 compounds analysed was assessed based on the equivalency factors (TEF) of each individual hydrocarbon determined with respect to the carcinogenicity of $\mathrm{BaP}$, which was given a value of 1 (Table 1) (Nisbet \& Lagoy 1992, US EPA 1993, Villeneuve et al. 2002). The TEQ values were estimated as the sum of each PAH concentration multiplied by its specific TEF: TEQ $=\Sigma\left(\mathrm{C}_{i} \times \mathrm{TEF}_{i}\right)$, where $\mathrm{C}_{i}$ is the concentration of PAH $i$.

\section{Samples preparation for mutagenicity assay}

In a similar method as used by the mussel farmers, the tar samples were heated to make them more fluid. Then, the water-accommodated fractions of all 4 samples were prepared based on the recommendations of Singer et al. (2000). Each sample was dissolved in a minimum volume of dimethyl sulfoxide (DMSO) or acetone and diluted while stirred up to concentrations of 10 and $40 \mathrm{mg} \mathrm{l}^{-1}$ with artificial seawater, prepared according to MacLeod et al. (1954). Solutions were maintained in darkness at $20^{\circ} \mathrm{C}$. Similarly, 6, 20, and $40 \mu \mathrm{g} \mathrm{l}^{-1}$ of BaP were prepared and taken as a mutagen reference. The BaP concentrations assayed were within the range used by the legally recognised mutagenicity tests (2 to $500 \mathrm{ng}$ $\mathrm{ml}^{-1}$ ). The concentrations of tars and paint were determined basing on our previous papers about PAHs and metals accumulated in cultured mussels from the Ría of Vigo (Ruiz et al. 2011, 2013). To test the possible mutagenicity of the solvents used, 3:10 
dilutions of DMSO and acetone were prepared in artificial seawater to achieve the same concentrations as in the samples. For the analyses of metabolic activation, BaP tars, WP and solvents were prepared at $50 \times$ concentration.

\section{Metabolic activation}

Metabolic activation of tested samples was performed with microsomes collected in the supernatant after centrifugation at $9.000 \times g(\mathrm{~S} 9)$ of the liver of a male Wistar Han rat, whose detoxification metabolism had been induced by administration of Aroclor (500 $\mathrm{mg} \mathrm{kg}^{-1}$ of weight) for $1 \mathrm{wk}$ before sacrifice (BD Biosciences). The protein concentration of the S9 extract was $20 \mathrm{mg} \mathrm{ml}^{-1}$, containing $470 \mathrm{pmol} \mathrm{mg}^{-1}$ cytochrome P450, $610 \mathrm{pmol} \mathrm{mg}^{-1}$ cytochrome b5, and the following enzymatic activities: $250 \mathrm{pmol} \mathrm{mg}^{-1}$ $\mathrm{min}^{-1}$ of cytochrome c reductase, $2700 \mathrm{pmol} \mathrm{mg}^{-1} \mathrm{~min}^{-1}$ testosterone 6 $\beta$-hydroxylase (CYP3A), $3100 \mathrm{pmol}$ $\mathrm{mg}^{-1} \mathrm{~min}^{-1}$ testosterone $16 \alpha$-hydroxylase (CYP2C),

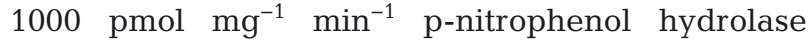
(CYP2E1), $210 \mathrm{pmol} \mathrm{mg}^{-1} \mathrm{~min}^{-1} 7$-ethoxyresorufin Odeethylase (CYP1A), and $1100 \mathrm{pmol} \mathrm{mg}^{-1} \mathrm{~min}^{-1}\left[{ }^{14} \mathrm{C}\right]$ lauric acid-hydrolase (CYP 4A).

The reaction mixture contained $100 \mathrm{mM}$ sodium phosphate buffer, $\mathrm{pH} 7.6,33 \mathrm{mM} \mathrm{KCl}, 8 \mathrm{mM} \mathrm{MgCl}_{2}$, a NADPH-generating system (4 mM NADP, $5 \mathrm{mM}$ glucose 6-phosphate, and $0.4 \mathrm{U} \mathrm{ml}^{-1}$ glucose 6-phosphate dehydrogenase), $10 \mu \mathrm{l} \mathrm{S9}$, and $100 \mu \mathrm{l}$ of the $50 \times$ concentration of the samples. The final volume of the reaction mixture was $0.5 \mathrm{ml}$. After incubation for $15 \mathrm{~min}$ at $30^{\circ} \mathrm{C}$, the reaction mixtures were sterilized by filtration through $0.22 \mu \mathrm{m}$ filters (Millipore) and diluted under stirring to a final volume of $5 \mathrm{ml}$ with artificial seawater to reach the concentrations indicated above to test.

\section{Mutagenicity assay}

The Vibrio harveyi strains used in the mutagenicity assay were kindly provided by Dr. G. Wegrzyn (University of Gdansk, Poland): wild-type BB7 strain (Belas et al. 1982); BB7X, a strain that is very sensitive to UV irradiation and that bears the Tn5TpMSC insertion (Czyz et al. 2000, 2001, Sikora et al. 2006); and analogous strains called BB7M and BB7XM bearing plasmid pAB91273 that contains mucA and $m u c B$ genes, responsible for enhanced errorproneDNA repair, in addition to ampicillin and chloramphenicol resistance genes (Czyz et al. 2000).
The mutagenicity assay was performed according to Czyz et al. (2000) slightly modified by Ruiz et al. (2013). The culture medium used was BOSS broth (Klein et al. 1995), hydrated with artificial marine water (Marine BOSS Broth). For growth of BB7M and BB7XM strains, $50 \mu \mathrm{g} \mathrm{ml}^{-1}$ ampicilin and $35 \mu \mathrm{g} \mathrm{ml}^{-1}$ chloramphenicol were added.

$V$. harveyi strains were cultured at $30^{\circ} \mathrm{C}$ to mid-log phase $\left(\mathrm{OD}_{575}\right.$ approx. 0.5). Then, $5 \mathrm{ml}$ of each culture were centrifuged $(5.000 \times g, 20 \mathrm{~min})$, and the bacterial pellet was resuspended in an equal volume of the samples (without and with metabolic activation) or of artificial marine water (control sample). After incubation over 1 generation $\left(2 \mathrm{~h}\right.$ at $30^{\circ} \mathrm{C}$ ), bacterial suspensions were diluted in artificial seawater. Surviving cells were titrated on Marine BOSS plates, spreading $100 \mu$ of a $1: 10^{6}$ dilution. Mutant cells were titrated on the same culture medium with neomycin $(50 \mu \mathrm{g}$ $\mathrm{ml}^{-1}$ ), spreading $100 \mu \mathrm{l}$ of a 1:10 dilution. Following incubation at $30^{\circ} \mathrm{C}$ for 24 to $48 \mathrm{~h}$, colony-forming units (CFU ml ${ }^{-1}$ ) were counted. All assays were performed in triplicate.

The mutation frequency is defined as the percentage of mutants with respect to survivors quantified in plates after exposure of the Vibrio culture to artificial marine water (spontaneous mutation frequency) or to the samples (induced mutation frequency). The ratio between the induced mutation frequency and the spontaneous mutation frequency provides the mutagenicity index (MI), which expresses the increase of the spontaneous mutation frequency, in absolute values, due to mutagen action. According to Ames et al. (1975), compounds that increase the spontaneous mutation frequency by 1.5 - to 2 -fold are considered potentially mutagenic ( $\mathrm{MI}=1.5$ to 2$)$, and those that increase it $\geq 2$-fold are considered mutagenic compounds (MI $\geq 2$ ). The bacterial mortality caused by the analysed samples was determined by calculating the percentage of survivors with respect to those in artificial seawater.

\section{Statistical analysis}

Statistical analysis was performed with SPSS 17.0 (SPSS). The distribution and homoscedasticity of all data were analysed by Kolmogorov-Smirnov and Levene tests, respectively. The data variations were assessed by Students's t-test or 1-way analysis of variance (ANOVA). In the latter, when ANOVA indicated significant differences, a Tukey's post-hoc test was used to determine significant differences be- 
tween groups. In both, the results were considered significant at $\mathrm{p}<0.05$.

\section{RESULTS AND DISCUSSION}

\section{Chemical composition}

The maintenance and cleaning of mussel rafts is usually performed in situ with tars or waterproof paints, as described in the introduction. The most widely used of these compounds is an arbitrary mixture of petroleum tars and diesel combusted oil, followed in quantitative importance by coal and pine tars. The pine tar ist only initially used when the raft is installed due its higher cost. Recently, some fishermen have started using antifouling paint for these tasks.

The composition in hydrocarbons (13 parent PAHs) of these compounds is shown in Table 2. The WP is based on metallic oxides and artificial or vegetal resins, but no hydrocarbons were detected. The MTO contained PAHs concentrations ( $\Sigma 13$ parent PAHs) 200- and 256-fold greater than the CT and the PT, respectively. These latter showed similar hydrocarbon concentrations, although notable differences in their composition were observed: the coal tar presented a significantly greater percentage of PAHs with 3 benzene rings, and the pine tar contained more PAHs with 5 and 6 benzene rings ( $p<0.01$ ). Moreover, PAHs of 4 benzene rings were predominant in the arbitrary mixture of petroleum tars and

Table 2. Hydrocarbon composition of different tars commonly used in the cleaning and maintenance of mussel rafts $\left(\mathrm{mg} \mathrm{kg}^{-1}\right)$. TEQ: toxic equivalency relative to BaP. MTO: mixture of petroleum tars and diesel combusted oil; CT: coal tar; PT: tar of pine wood. Other abbreviations as in Table 1

\begin{tabular}{|lrrr|}
\hline & \multicolumn{1}{c}{ MTO } & CT & PT \\
\hline Phe & 13358.00 & 126.77 & 23.48 \\
An & 2270.00 & 12.94 & 4.57 \\
Flt & 7015.00 & 6.48 & 9.34 \\
Py & 3817.30 & 15.26 & 3.06 \\
BaA & 3243.00 & 1.82 & 2.85 \\
Chry & 3210.00 & 9.63 & 29.69 \\
BbF & 1774.60 & 10.24 & 25.94 \\
BkF & 874.60 & 3.75 & 3.50 \\
BeP & 1404.20 & 10.48 & 43.35 \\
BaP & 1569.10 & 1.96 & 0.32 \\
DBA & 217.00 & 0.49 & 1.25 \\
Bper & 576.50 & 1.06 & 10.50 \\
IP & 1033.00 & 0.00 & 0.00 \\
LPAHs & 40362.30 & 200.88 & 157.85 \\
TEQ & 2563.37 & 4.41 & 5.27 \\
\hline
\end{tabular}

diesel combusted oil ( $\mathrm{p}<0.01$ ) (Fig. 2). PAHs containing 4 or more benzene rings are less water soluble and biodegradable, therefore tending to accumulate persistently (Jaward et al. 2004).

Pollutants accumulated in filtering organisms are indicative of a pollutant spill in the environment. For this reason, mussels and other bivalves have been established as sentinel organisms in monitoring programs (Goldberg et al. 1978, O'Connor 2002). Between 50 and $62 \%$ of the total accumulated PAHs in mussels cultured in the Ría of Vigo are hydrocarbons with 4 benzene rings (Ruiz et al. 2011). This percentage is similar to that found in the MTO (43\%) (Fig. 2) and seems to agree with the preferential use of this mixture for raft cleaning.

The composition of a hydrocarbon mixture can identify its origin. In this regard, rates of different PAHs have been generally used as molecular indices to determine the process by which a hydrocarbon is generated: petrogenic origin (oil, diesel, or coal) and pyrolytic origin by petroleum combustion (vehicle and crude oil) or by biomass combustion (grass, wood, or coal) (Budzinski et al. 1997). In the present study, 6 of these indices were used to interpret the genesis of the tars analysed: Phe/An; An/An+Phe; Flt/Py; Flt/Flt+Py; BaA/BaA+Chry; IP/IP+Bper. Their range of values is summarized in Table 3A. Magi et al. (2002) also suggest the use of BaP as another molecular marker of PAH derivatives combustion since BaP is present in very low proportions in petroleum while it is abundantly formed during incomplete combustion. The values of these indices for the analysed tars (Table 3B) clearly evidenced the pyrolytic genesis of the MTO, while CT and PT seemed to be generated by mixed petrogenic and

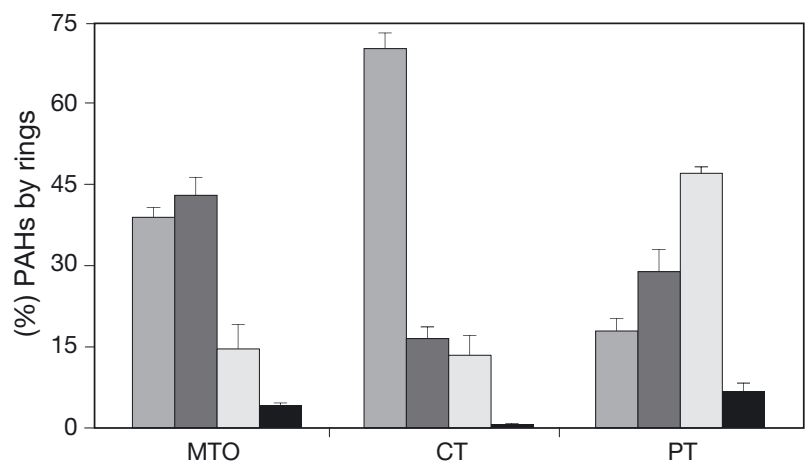

Fig. 2. Hydrocarbon families contained in different tar mixtures used to clean mussel rafts as a percentage of the total PAHs ( $\Sigma 13$ PAHs). Error bars $=1 \mathrm{SD}$. Significant variation ( $<<0.01$; Tukey's test). 3-ring PAHs; 4-ring PAHs; 5ring PAHs; 6-ring PAHs. MTO: mixture of petroleum tars and diesel combusted oil; CT: coal tar; PT: tar of pine wood 
Table 3. Molecular indices used as fingerprints to determinate the pyrolytic or petrogenic origin of a hydrocarbon (Colombo et al. 1989, Budzinski et al. 1997, Baumard et al. 1998a,b, Soclo et al. 2000, Yunker et al. 2002a,b). (B) Values of these molecular indices of 3 different tars used in cleaning of mussel rafts. MTO: mixture of petroleum tars and diesel combusted oil; CT: coal tar; PT: tar of pine wood; $(\square)$ petrogenic origin; $(\square)$ pyrolitic origin; (no shading) mixed origin. Other abbreviations as in Table 1

\begin{tabular}{|c|c|c|c|c|}
\hline \multirow{2}{*}{$\begin{array}{l}\text { (A) Molecular } \\
\text { index }\end{array}$} & \multirow{2}{*}{$\begin{array}{c}\text { Petrogenic } \\
\text { origin }\end{array}$} & \multicolumn{2}{|c|}{ Pyrolitic origin } & \multirow{2}{*}{$\begin{array}{l}\text { Mixed } \\
\text { origin }\end{array}$} \\
\hline & & $\begin{array}{c}\text { Petroleum } \\
\text { combustion }\end{array}$ & $\begin{array}{c}\text { Biomass } \\
\text { combustion }\end{array}$ & \\
\hline Phe/An & $>15$ & $<10$ & $<10$ & $10-15$ \\
\hline $\mathrm{An} / \mathrm{An}+\mathrm{Phe}$ & $<0.10$ & $>0.10$ & $>0.10$ & \\
\hline Flt/Py & $<1$ & $>1$ & $>1$ & \\
\hline Flt/Flt+Py & $<0.40$ & $0.40-0.50$ & $>0.50$ & \\
\hline $\mathrm{BaA} / \mathrm{BaA}+\mathrm{Chry}$ & $<0.20$ & $>0.35$ & $>0.35$ & $0.20-0.35$ \\
\hline IP/IP+Bper & $<0.20$ & $0.20-0.50$ & $>0.50$ & \\
\hline (B) & & MTO & $\mathrm{CT}$ & $\mathrm{PT}$ \\
\hline Phe/An & & 5.89 & 9.80 & 5.14 \\
\hline $\mathrm{An} / \mathrm{An}+\mathrm{Phe}$ & & 0.15 & 0.09 & 0.16 \\
\hline Flt/Py & & 1.82 & 0.43 & 3.05 \\
\hline Flt/Flt+Py & & 0.65 & 0.30 & 0.75 \\
\hline $\mathrm{BaA} / \mathrm{BaA}+\mathrm{Chry}$ & & 0.50 & 0.16 & 0.09 \\
\hline $\mathrm{IP} / \mathrm{IP}+\mathrm{Bper}$ & & 0.64 & 0.00 & 0.00 \\
\hline$\% \mathrm{BaP}$ & & 3.89 & 0.98 & 0.20 \\
\hline
\end{tabular}
origin of hydrocarbons. (A) Characteristic values indicative of the

the Ría of Vigo, demonstrating a chronic accumulation of pyrolytic hydrocarbons that increases in spring-summer. This is the season when the rafts are usually cleaned.

Heavy and trace metals are considered the most studied pollutant group in coastal environments because of their wide distribution, persistence, and toxicity. These metals are included in diverse industrial compounds, such as fuels and tars, lubricants, catalysts, paint drying agents, pigments, or pesticides (Laws 2000, Clark 2001). Some, such as Mn, $\mathrm{Zn}$, and $\mathrm{Cu}$, have physiological functions in living organisms but at high concentrations are also toxic (Goyer \& Clarkson 2001). These metals are persistent because they are not biodegradable and they tend to accumulate in the food chain (Facchinelli et al. 2001). The trace metal content of the tested compounds is summarized in Table 4. The composition significantly differed between the tars and the waterproof paint. The WP showed significantly higher concentrations of $\mathrm{Mn}, \mathrm{Cr}, \mathrm{Cu}, \mathrm{Sn}$, and $\mathrm{Ni}(\mathrm{p}<0.01)$, while the tars were characterized by their significantly high concentration of $\mathrm{Zn}$ and $\mathrm{Pb}(\mathrm{p}<$ 0.01). Some differences were also observed pyrolytic processes. However, the predominant process for the CT and PT genesis seemed to differ: petrogenic for CT and pyrolytic for PT. These indices were also used by Ruiz et al. (2011) to determine the origin of PAHs accumulated in cultured mussels from

Table 4. Trace metal content of different compounds commonly used to clean and maintain mussel rafts $\left(\mathrm{mg} \mathrm{kg}^{-1}\right)$. MTO: mixture of petroleum tars and diesel combusted oil; C: coal tar; PT: tar of pine wood; WP: waterproof paint. * Significant increase of metal concentration in the WP relative to the tars analysed and in the tars relative to the $\mathrm{WP}_{i}{ }^{\mathrm{a}}$ significant increase of metal concentration in each tar analysed regarding the other tars $(\mathrm{p}<0.01)$ (Tukey's test)

\begin{tabular}{|lcccc|}
\hline Metal & MTO & CT & PT & WP \\
\hline $\mathrm{As}$ & $<5$ & $<5$ & $<5$ & $<5$ \\
$\mathrm{Cd}$ & $<1$ & $<1$ & $<1$ & $<1$ \\
$\mathrm{Cr}$ & 1.01 & 1.92 & $<1$ & $23.79^{*}$ \\
$\mathrm{Cu}$ & 0.98 & 1.48 & 1.86 & $14.32^{*}$ \\
$\mathrm{Mn}$ & $5.27^{\mathrm{a}}$ & 1.72 & 0.15 & $164.42^{*}$ \\
$\mathrm{Ni}$ & 1.54 & $3.21^{\mathrm{a}}$ & $<1$ & $8.05^{*}$ \\
$\mathrm{Sn}$ & $<4$ & $<4$ & $<4$ & $12.09^{*}$ \\
$\mathrm{~Pb}$ & $9.67^{*, a}$ & $2.84^{*}$ & $2.69^{*}$ & $<1$ \\
$\mathrm{~V}$ & 2.44 & $9.77^{\mathrm{a}}$ & $<1$ & 3.95 \\
$\mathrm{Zn}$ & $37.89^{*}$ & $37.73^{*}$ & $38.28^{*}$ & 9.12 \\
$\mathrm{Hg}$ & $<0.01$ & $<0.01$ & $<0.01$ & $<0.01$ \\
\hline
\end{tabular}
between the tars: the MTO contained higher concentrations of $\mathrm{Pb}$ and $\mathrm{Mn}(\mathrm{p}<0.01)$, while the CT showed higher concentrations of $\mathrm{V}$ and $\mathrm{Ni}(\mathrm{p}<0.01)$.

According to our previous results, the accumulation of heavy and trace metals in cultured mussels in the Ría of Vigo follows a seasonal pattern, with maximum concentrations in the spring and summer (Ruiz 2012, Ruiz et al. 2011, 2013). These works describe a significant accumulation of Zn (88\%) and, in smaller proportions, of $\mathrm{As}(6.1 \%), \mathrm{Cu}(3.3 \%)$ and $\mathrm{Pb}(1.4 \%)$, highly correlated with accumulation of IP. Among the compounds analysed in this work, only the MTO contained IP (Table 1), which again confirms the predominant use of this mixture in mussel farms.

Although the hydrocarbon and metal pollution can have a diverse source, the data shown seem to agree with the habitual use of the MTO in cleaning of mussel rafts and with the hydrocarbon class accumulated in mussels, confirming the contribution of these cleaning tasks to pollution of aquaculture areas.

\section{Toxic equivalency}

Not all PAHs and heavy and trace metals have the same toxicity. Among hydrocarbons, the PAHs with 3 
Table 5. Toxic equivalency (TEQ) values of the different concentrations of $\mathrm{BaP}$ and tar mixtures used in the Vibrio harveyi mutagenicity test. (-): concentration not tested. Abbreviations as in Tables $1 \& 2$

\begin{tabular}{|lcccc|}
\hline $\begin{array}{l}\text { Concentration } \\
\left(\mathrm{mg} \mathrm{l}^{-1}\right)\end{array}$ & BaP & \multicolumn{4}{c|}{ TEQ values $\left(\times 10^{3}\right)$} \\
\hline $6 \times 10^{-3}$ & 6.00 & - & - & - \\
$20 \times 10^{-3}$ & 20.00 & - & - & - \\
$40 \times 10^{-3}$ & 40.00 & - & - & - \\
10 & - & 25.60 & 0.04 & 0.05 \\
40 & - & 102.50 & 0.18 & 0.21 \\
\hline
\end{tabular}

and 4 benzene rings are considered toxic but not carcinogenic. However, the PAHs containing 5 to 7 benzene rings are also highly mutagenic, carcinogenic, and teratogenic (Lehr \& Jerina 1977, WHO 1989, Boström et al. 2002). The toxicological risk of the tars analysed was calculated as their toxic equivalency (TEQ) in relation to the BaP toxicity.

The toxic equivalency of the MTO was 581- and 486-fold higher than that of the $\mathrm{CT}$ and $\mathrm{PT}$, respectively (Table 2). Although the PAH concentration in the PT was 1.3-fold less than that in the CT, its TEQ value was somewhat higher (Table 2) due to its larger percentage of PAHs with 5 and 6 benzene rings (Fig. 2), among which the most toxic compounds are present. Table 5 shows the toxic equivalency of the tars concentrations used in the mutagenicity test. The theoretical toxicity (TEQ value) of 10 and $40 \mathrm{mg} \mathrm{l}^{-1}$ of the MTO was 1.3- and 5.1-fold higher than that of $20 \mathrm{\mu g} \mathrm{l}^{-1}$ of BaP, respectively. However, the TEQ values calculated for the same concentrations of the $\mathrm{CT}$ and PT were 2 or 3 orders of magnitude lower than the BaP concentrations taken as a reference.

The toxicity of metals is mainly due to their affinity for sulphured and nitrogenised residues of biomolecules such as proteins (Nieboer \& Richardson 1980, Rainbow 2006), which alters cation homeostasis $\left(\mathrm{Ca}^{+2}\right.$ and $\left.\mathrm{Mg}^{+2}\right)$, affecting transport through the cell membrane, respiration rate, and metabolism and inducing oxidative stress (Khangarot \& Rathore 2003, Muyssen et al. 2006). Among heavy and trace metals, $\mathrm{Hg}, \mathrm{Cd}$, and $\mathrm{Pb}$ are considered especially dangerous because of their toxicity, even at low concentrations, followed at some distance by $\mathrm{Cu}, \mathrm{Zn}$, and As, which also have mutagenic and carcinogenic effects (Florea \& Büsselberg 2006, Prá et al. 2008, Obiakor et al. 2010).

As shown in Table 4, the tars analysed contained high concentrations of $\mathrm{Zn}\left(\sim 38 \mathrm{mg} \mathrm{kg}^{-1}\right)$ and $\mathrm{Pb}(2.7$ to $9.7 \mathrm{mg} \mathrm{kg}^{-1}$ ). The $\mathrm{Pb}$ concentration of the MTO was 3.5-fold higher than that of the CT and PT, and the $\mathrm{CT}$ also contained significant concentrations of $\mathrm{V}$, which has been related to development disorders, diseases of the nervous, hematologic, and immune systems, and cancer development (Mitchell 2007, ATSDR 2012). Moreover, the waterproof paint analysed contained a significant proportion of $\mathrm{Cu}$ and high $\mathrm{Mn}$ and $\mathrm{Cr}$ concentrations. These latter 2 metals, although they have a moderate toxicity, have been related to nervous, hepatic, and lung pathologies as well as to male reproductive diseases. Furthermore, Cr has carcinogenic effects (ATSDR 2004, 2012, Crossgrove \& Zheng 2004).

The theoretical toxicity of the compounds used in the maintenance and cleaning of mussel rafts seems to agree with the observation of gonadal neoplastic disorders in mussels cultured in the Ría of Vigo, whose development is directly related to accumulation of hydrocarbons and metals, mainly PAHs with 4 to 6 benzene rings, $\mathrm{Zn}$, and Cd (Alonso et al. 2001, Ruiz et al. 2013, 2014).

\section{Mutagenicity}

In previous sections, we identified the theoretical toxicity of the mixtures used to clean rafts in mussel farms based on their composition. However, conditions of the marine environment such as salinity and temperature may modify the solubility and bioavailability of chemicals and therefore their toxicity (McElroy et al. 1989, Singer et al. 2000, Schlautman et al. 2004). Furthermore, the biodegradation processes in living organisms can generate metabolic products more toxic than the parent compounds, thus increasing their harmful effect (Lehr \& Jerina 1977, Stegeman 1981, López-Barea \& Pueyo 1998). Therefore, the evaluation of marine pollutants toxicity should be performed using biological assays under similar conditions to those of the studied environment.

The most commonly used toxicity assay is the Ames mutagenicity test, based on the reversion detection of histidine-auxotrophic mutants of Salmonella typhimurium strains, after their exposure to mutagens (Ames 1971, Maron \& Ames 1983, Mortelmans \& Zeiger 2000). However, the survival of $S$. typhimurium is dramatically reduced in marine water (Czyz et al. 2002, Ohe et al. 2004), so other mutagenicity assays using marine bacteria have been developed based on detection of reversion of dark mutants of Vibrio fischeri and $V$. harveyi or on detection of neomycin-resistant mutants of $V$. harveyi strains (Kwan et al. 1990, Czyz et al. 2000, 2002, 2003, Podgórska \& Wegrzyn 2006, Słoczynska et al. 2010). In the present study, the latter assay was 


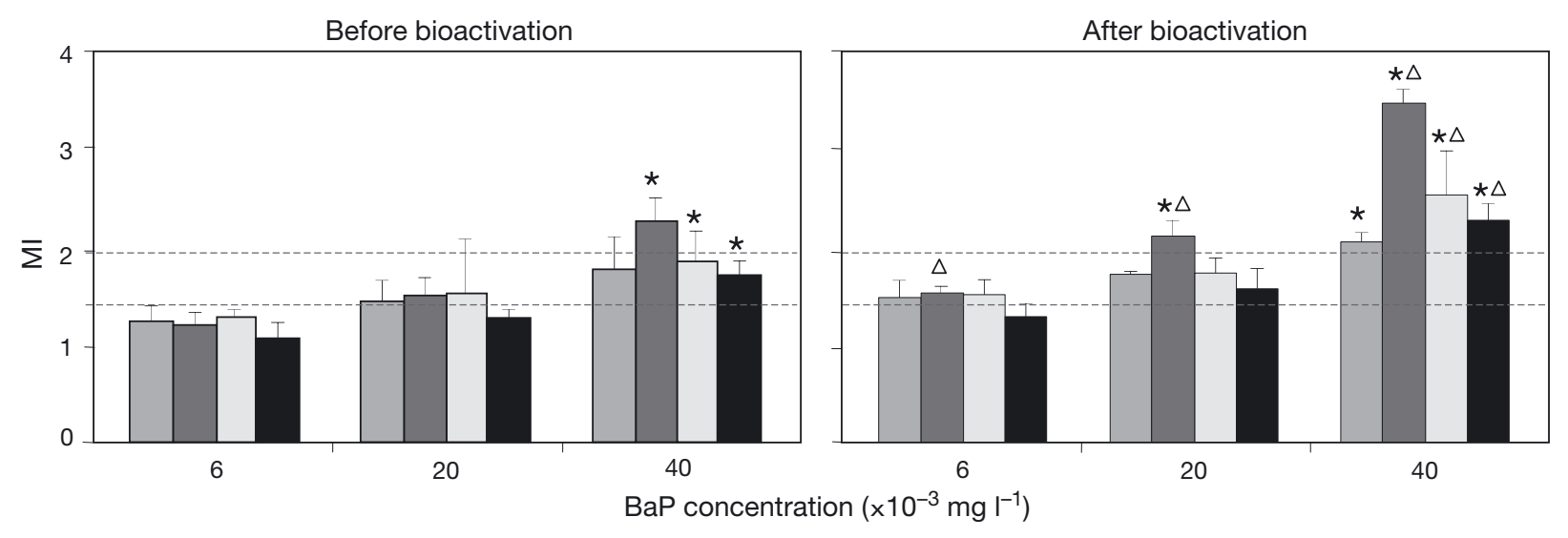

Fig. 3. Mutagenicity index (MI) of different concentrations of BaP analysed using the Vibrio harveyi test. Error bars $=1 \mathrm{SD}$. The assay was performed with 4 different bacterial strains, before and after metabolic activation with the S9 fraction from the liver of male Wistar Han rat. V. harveyi strains: BB7 $(\square)$; BB7M ( $\square$ ); BB7X $(\square)$ and BB7XM $(\square)$. Limits of MI values (dashed lines): potentially mutagenic $(1.5<\mathrm{MI}<2)$ and mutagenic $(\mathrm{MI}>2)$. $*$ : significant increase of $\mathrm{MI}$ with the BaP concentration $(\mathrm{p}<0.05) ; \Delta$ : significant increase of MI after metabolic activation $(\mathrm{p}<0.05)$ (Tukey's test)

selected for mutagenicity analysis of the cleaning mixtures used in mussel farms because of its greater sensitivity, simplicity, and low cost (Johnson 1992, Podgórska \& Wegrzyn 2006, Chec et al. 2008, Ruiz et al. 2013).

Taking this into account, the mutagenic capacity of the water-accommodated fractions from the tars and the waterproof paint, before and after being metabolised by mouse liver microsomes, were tested in comparison to the mutagenic activity of BaP. The results are reported in Figs. $3 \& 4$.

The DMSO and acetone concentrations used as the solvents showed no mutagenic effects on any of the 4 strains of $V$. harveyi on which the test was based, giving mutation frequencies similar to the spontaneous mutation frequency. Survival of strains was $>95 \%$ in all the tests performed, demonstrating the suitability of the concentrations used in the mutagenicity test.

$\mathrm{BaP}$ is considered a premutagen whose epoxide, originated by microsomal metabolism, is a potent mutagen that interacts with DNA. The Ames test identifies this compound as a mutagen that increases its mutagenic capacity after metabolic activation (Ames et al. 1972, Maria et al. 2002, Jemnitz et al. 2004). In agreement with this, our results of the $V$. harveyi test showed a significant increase of the MI of BaP after its metabolic transformation $(p<0.1)$ (Fig. 3). Each strain used in this test showed a different sensitivity, as described by Czyz et al. (2000, 2002). However, the 4 presented a dose-dependent MI increment with respect to the concentrations of $\mathrm{BaP}(\mathrm{p}<0.05)$. Before metabolic activation, only the highest concentration of $\mathrm{BaP}\left(40 \mu \mathrm{g} \mathrm{l}^{-1}\right)$ showed mutagenic or potentially mutagenic effects. But after metabolic activation, the lowest concentration $(6 \mu \mathrm{g}$ $\mathrm{l}^{-1}$ ) also showed potentially mutagenic effects, whereas the highest concentration increased the MI nearly 2 -fold (Fig. 3). These results prove the validity of the $V$. harveyi test and its proportional response to the dose of the mutagen and metabolic activation.

Regarding the tars analysed, statistically significant proportional responses were observed according to dose and metabolic activation $(\mathrm{p}<0.05)$ (Fig. 4). The MTO showed mutagenic effects clearly higher than those of the CT and the PT, but not proportional as would be expected by its much higher concentration of PAHs and toxic equivalency. The MI of MTO was also lower than expected with respect to the mutagenicity of $\mathrm{BaP}$, so that concentrations of 10 and $40 \mathrm{mg} \mathrm{l}^{-1}$ of MTO showed similar values to 20 and $40 \mu \mathrm{g} \mathrm{l}^{-1}$ of BaP respectively, both before and after metabolic activation. The concentration of $10 \mathrm{mg} \mathrm{l}^{-1}$ of MTO showed mutagenic values (>2) only after metabolic activation, but the concentration of $40 \mathrm{mg} \mathrm{l}^{-1}$ also showed mutagenic effects before metabolic activation.

Although the CT had a toxic equivalency somewhat lower than that of the PT (Table 5), it showed higher mutagenic effects (Fig. 4), probably due to the higher concentration of $\mathrm{BaP}$ and other less toxic PAHs such as Phe, An, and Py in its composition, which could have a synergistic effect enhancing the toxicity. Of these 2 tars, only the CT showed mutagenic effects after metabolic activation at the concentration of $40 \mathrm{mg} \mathrm{l}^{-1}(\mathrm{MI}=2.1$ to 2.4 ). This same concentration of the PT after metabolic activation only showed potentially mutagenic values $(\mathrm{MI}=1.6$ to 1.8 ). 

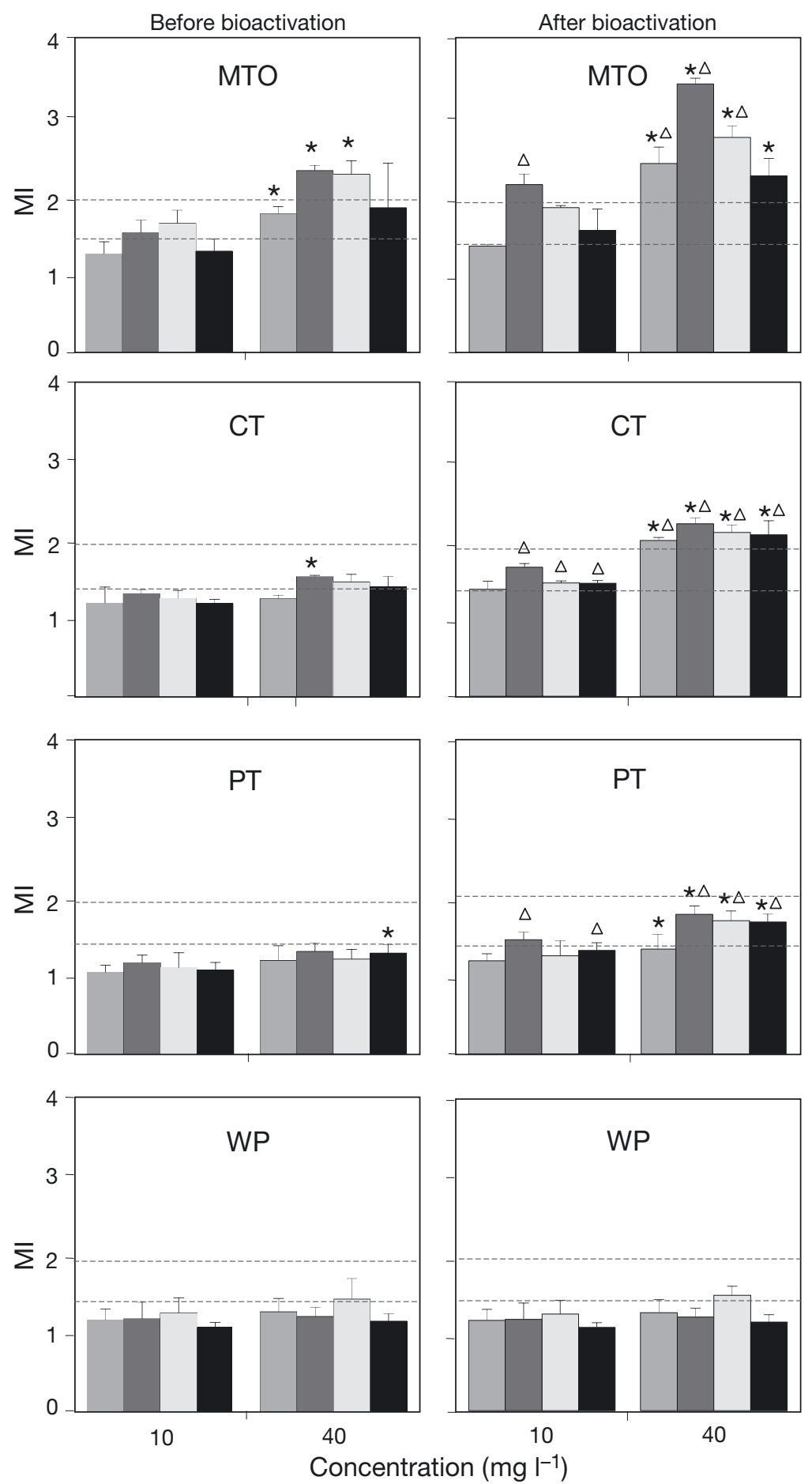

Fig. 4. Mutagenicity index (MI) of different concentrations of compounds used to clean mussel rafts analysed by the Vibrio harveyi test before and after metabolic activation with the S9 fraction from the liver of male Wistar Han rat. Bars = $1 \mathrm{SD}$. Tested compounds: mixture of petroleum tars and diesel combusted oil (MTO); commercial coal tar $(\mathrm{CT})$; tar of pine wood

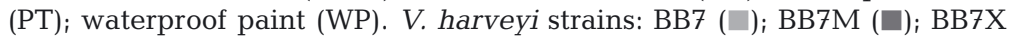
$(\square)$, and BB7XM (ם). Limits of MI values (dashed lines): potentially mutagenic $(1.5<\mathrm{MI}<2)$ and mutagenic $(\mathrm{MI}>2)$. $*$ : significant increase of MI with the compounds concentration $(p<0.01) ; \Delta$ : significant increase of MI after metabolic activation $(\mathrm{p}<0.01)$ (Student $t$-test)
The tars analysed are complex and variable mixtures whose bioavailability and toxic potential depend, as indicated above, on their solubility and partition coefficients, potentially explaining the results observed, which differed slightly from those expected. The solubility and partition coefficient, in turn, vary depending on environmental conditions, such as salinity and temperature, but also on the concentration and composition of mixture itself, decreasing as the concentration of total hydrocarbons and the proportion of high molecular weight PAHs increase (Singer et al. 2000, Prak \& Pritchard 2002, Schlautman et al. 2004).

Moreover, the waterproof paint showed no mutagenic effects, and its MI values were $<1.5$ at all concentrations assayed, before and after metabolic activation. Heavy and trace metals are persistent pollutants that are not biodegradable (Facchinelli et al. 2001), which justifies that this paint, composed of metallic oxides, does not display bioactivation. As indicated above, acute and chronic exposure to some heavy metals and their bioacumulation has been related to carcinogenesis. However, their concentrations in the dilutions assayed of the waterproof paint seem very low and are unlikely to drive any mutagenic effect compared to the mutagenicity of PAHs.

\section{CONCLUSION}

Our results suggest the convenience of regulation and control of the maintenance tasks of mussel rafts, allowing only compounds with a low toxic risk. The data shown here reveal that the use of waterproof paints and pine tar would be suitable for the maintenance of rafts and could reduce the pollutant impact in the mussel farms. Nevertheless, if these compounds are used regularly, monitoring of the accumulation in mussels of the heavy metals and the PAHs of high molecular weight that the compounds contain should be performed. 
Acknowledgements. The authors are very grateful to Dr. G. Wegrzyn (Gdansk University) for kindly providing the strains of Vibrio harveyi as well as to Antonio Antepazos and the fishermen of 'Antepazos I', who provided the compounds used in cleaning and maintenance of mussel rafts. We also thank the Spanish Institute of Oceanography and the Centre for Scientific and Technological Support to Research of the University of Vigo, where the analysis of PAHs and metals was conducted. This work was supported by a grant from the Autonomous Galician Government (PGIDIT10MDS312030PR).

\section{LITERATURE CITED}

Agency for Toxic Substances and Disease Registry (ATSDR) (2004) Toxicological profile for copper. US Department of Health and Human Services, Public Health Service, Atlanta, GA

Agency for Toxic Substances and Disease Registry (ATSDR) (2012) Toxicological profile for chromium, manganese and vanadium. US Department of Health and Human Services, Public Health Service, Atlanta, GA

Alonso A, Suárez P, Álvarez C, San Juan F, Molist P (2001) Structural study of a possible neoplasia detected in Mytilus galloprovincialis collected from the Ría of Vigo (NW Spain). Dis Aquat Org 47:73-79

Ames BN (1971) The detection of chemical mutagens with enteric bacteria. In: Hollaender A (ed) Chemical mutagens, principles and methods for their detection, Vol 1. Plenum Press, New York, NY, p 267-282

Ames BN, Sims P, Grover PL (1972) Epoxides of polycyclic hydrocarbons are frameshift mutagens. Science 176: $47-49$

$>$ Ames BN, Mc. Cann J, Yamasaki E (1975) Methods for detecting carcinogens and mutagens with the Salmonella/mammalian-microsome mutagenicity test. Mutat Res 31:347-364

Barton HA, Cogliano VJ, Flowers L, Valcovic L, Setzer RW, Woodruff TJ (2005) Assessing susceptibility from earlylife exposure to carcinogens. Environ Health Perspect 113:1125-1133

Baumard P, Budzinski H, Michon Q, Garrigues P, Burgeot T, Bellocq J (1998a) Origin and bioavailability of PAHs in the Mediterranean Sea from mussel and sediment records. Estuar Coast Shelf Sci 47:77-90

Baumard P, Budzinski H, Garrigues P (1998b) PAHs in Arcachon Bay, France: origin and biomonitoring with caged organisms. Mar Pollut Bull 36:577-586

Baumard P, Budzinski H, Garrigues P, Narbonne JF, Burgeot T, Michel X, Bellocq J (1999) Polycyclic aromatic hydrocarbon (PAH) burden of mussels (Mytilus spp.) in different marine environments in relation with sediment $\mathrm{PAH}$ contamination, and bioavailability. Mar Environ Res 47: 415-439

> Belas R, Mileham A, Cohn D, Hilmen M, Simon M, Silverman M (1982) Bacterial luminescence: isolation and expression of the luciferase genes from Vibrio harveyi. Science 218:791-793

$>$ Boström CE, Gerde P, Hanberg A, Jernström B and others (2002) Cancer risk assessment, indicators, and guidelines for polycyclic aromatic hydrocarbons in the ambient air. Environ Health Perspect 110:451-488

Budzinski H, Jones I, Bellocq J, Pierard C, Garrigues P
(1997) Evaluation of sediment contamination by polycyclic aromatic hydrocarbon in the Gironde estuary. Mar Chem 58:85-97

Caballero Miguez G, Garza Gil MD, Varela Lafuente MM (2009) The institutional foundations of economic performance of mussel production: the Spanish case of the Galician floating raft culture. Mar Policy 33:288-296

Chec E, Podgórska B, Wegrzyn G (2008) Comparison of the use of mussels and semipermeable membrane devices for monitoring and assessment of accumulation of mutagenic pollutants in marine environment in combination with a novel microbiological mutagenicity assay. Environ Monit Assess 140:83-90

Clark RB (2001) Marine pollution, 5th edn. Oxford University Press, New York, NY

> Colombo JC, Pelletier E, Brochu C, Khalil M, Cataggio LA (1989) Determination of hydrocarbon sources using nalkanes and polyaromatic hydrocabon distribution indices. Case study: Río de la Plata estuary, Argentina. Environ Sci Technol 23:888-894

> Crossgrove J, Zheng W (2004) Manganese toxicity upon overexposure. NMR Biomed 17:544-553

> Czyz A, Jasiecki J, Bogdan A, Szpilewska H, Wegrzyn G (2000) Genetically modified Vibrio harveyi strains as potential bioindicators of mutagenic pollution of marine environments. Appl Environ Microbiol 66:599-605

> Czyz A, Zielke R, Konopa G, Wegrzyn G (2001) A Vibrio harveyi insertional mutant in the cgtA (obg, yhbZ) gene, whose homologues are present in diverse organisms ranging from bacteria to humans and are essential genes in many bacterial species. Microbiology 147:183-191

Czyz A, Szpilewska H, Dutkiewitcz R, Kowalska W, Biniewska-Godlewska A, W grzyn G (2002) Comparison of the Ames test and a newly developed assay for detection of mutagenic pollution of marine environments. Mutat Res 519:67-74

Czyz A, Kowalska W, Wegrzyn G (2003) Vibrio harveyi mutagenicity assay as a preliminary test for detection of mutagenic pollution of marine water. Bull Environ Contam Toxicol 70:1065-1070

Durán Neira C, Acuña Castroviejo R, Santiago Caamaño J (1990) El mejillón: Biología, cultivo y comercialización. In: Fundación Caixa Galicia (Aula del Mar) (ed) Serie Estudios Sectoriales, Book 5. Fundación Caixa Galicia, La Coruña, p 33-41

- Facchinelli A, Sacchi E, Mallen L (2001) Multivariate statistical and GIS-based approach to identify heavy metal source in soils. Environ Pollut 114:313-324

- Florea AM, Büsselberg D (2006) Occurrence, use and potential toxic effects of metals and metal compounds. Biometals 19:419-427

Goldberg ED, Bowen VT, Farrington JW, Harvey G and others (1978) The mussel watch. Environ Conserv 5:101-125

Goyer RA, Clarkson TW 2001. Toxic effect of metals. In: Klaassen CD (ed) Toxicology: the basic science of poisons. McGraw-Hill, New York, NY, p 811-868

> Jaward FM, Barber JL, Booij K, Jones C (2004) Spatial distribution of atmospheric PAHs and PCNs along a north south Atlantic transect. Environ Pollut 132:173-181

Jemnitz K, Veres Z, Torok G, Toth E, Vereczkey L (2004) Comparative study in the Ames test of benzo[a]pyrene and 2-aminoanthracene metabolic activation using rat hepatic S9 and hepatocytes following in vivo or in vitro induction. Mutagenesis 19:245-250 
Johnson BT (1992) An evaluation of a genotoxicity assay with liver S9 for activation and luminescent bacteria for detection. Environ Toxicol Chem 11:473-480

Khangarot BS, Rathore RS (2003) Effects of copper on respiration, reproduction and some biochemical parameters of water flea Daphnia magna Straus. Bull Environ Contam Toxicol 70:112-117

Klein G, Walczak R, Krasnowska E, Blaszczak A, Lipińska B (1995) Characterization of heat-shock response of the marine bacterium Vibrio harveyi. Mol Microbiol 16: 801-811

Kwan KK, Dutka BJ, Rao SS, Liu D (1990) Mutatox test: a new test for monitoring environmental genotoxic agents. Environ Pollut 65:323-332

Laws EA (2000) Aquatic pollution: an introductory text. Wiley, New York, NY

Lehr RE, Jerina DM (1977) Metabolic activation of polycyclic hydrocarbons. Arch Toxicol 39:1-6

> López-Barea J, Pueyo C (1998) Mutagen content and metabolic activation of promutagens by molluscs as biomarkers of marine pollution. Mutat Res 399:3-15

- MacLeod RA, Onofrey E, Norris ME (1954) Nutrition and metabolism of marine bacteria: survey of nutritional requirements. J Bacteriol 68:680-686

Magi E, Bianco R, Ianni C, Di Carro M (2002) Distribution of polycyclic aromatic hydrocarbons in the sediments of the Adriatic Sea. Environ Pollut 119:91-98

Maria VL, Correira AC, Santos A (2002) Benzo[a]pyrene and $\beta$-naphthoflavone mutagenic activation by European eel (Anguilla anguilla L.) S9 liver fraction. Ecotoxicol Environ Saf 53:81-85

Maron DM, Ames BN (1983) Revised methods for the Salmonella mutagenicity test. Mutat Res 113:173-215

McElroy AE, Farrington JW, Teal JM (1989) Bioavailability of polycyclic aromatic hydrocarbons in the aquatic environment. In: Varanassi U (ed) Metabolism of polycyclic aromatic hydrocarbons in the aquatic environment. CRC, Boca Raton, FL, p 1-39

Mitchell DC (2007) Toxicity of vanadium compounds: pulmonary and immune system targets. In: Kustin K, Pessoa JC, Crans DC (eds) Vanadium: the versatile metal. Advances in chemistry series no. 974. American Chemistry Society, Washington, DC, p 217-239

> Mortelmans K, Zeiger E (2000) The Ames Salmonella/microsome mutagenicity assay. Mutat Res 455:29-60

> Muyssen BTA, De Schamphelaere KAC, Janssen CR (2006) Mechanisms of chronic waterborne Zn toxicity in Daphnia magna. Aquat Toxicol 77:393-401

> Nieboer E, Richardson DHS (1980) The replacement of the nondescript term 'heavy metals' by a biologically and chemically significant classification of metal ions. Environ Pollut 1:3-26

> Nisbet ICT, La Goy PK (1992) Toxic equivalency factors (TEFs) for polycyclic aromatic hydrocarbons (PAHs). Regul Toxicol Pharmacol 16:290-300

> O'Connor TP (2002) National distribution of chemical concentrations in mussels and oysters in the USA. Mar Environ Res 53:117-143

Obiakor MO, Okonkwo JC, Ezeonyejiaku CD, Ezenwelu CO (2010) Genotoxicology: single and joint action of copper and zinc to Synodontis clarias and Tilapia nilotica. J Appl Sci Environ Manage 14:59-64

> Ohe T, Watanabe T, Wakabayashi K (2004) Mutagens in surface waters: a review. Mutat Res 567:109-149
Podgórska B, Wegrzyn G (2006) A modified Vibrio harveyi mutagenicity assay based on bioluminescence induction. Lett Appl Microbiol 42:578-582

Podgórska B, Wegrzyn G (2007) The use of marine bacteria in mutagenicity assays. Pol J Microbiol 56:227-231

Prá D, Franke SIR, Giulian R, Yoneama ML, Ferraz Dias J, Erdtmann B, Pêgas Henriques JA (2008) Genotoxicity and mutagenicity of iron and copper in mice. Biometals 21:289-297

> Prak DJ, Pritchard PH (2002) Solubilization of polycyclic aromatic hydrocarbon mixtures in micellar nonionic surfactant solutions. Water Res 36:3463-3472

Rainbow PS (2006) Biomonitoring of trace metals in estuarine and marine environments. Australas J Ecotoxicol 12: $107-122$

Ruiz Y (2012) Effects of pollutant episodes on the Mytilus galloprovincialis reproduction: cellular and metabolic alterations; defence mechanisms. PhD dissertation, University of Vigo

Ruiz Y, Suárez P, Alonso A, Longo E, Villaverde A, San Juan $F$ (2011) Environmental quality of mussel farms in the Vigo estuary: pollution by PAHs, origin and effects on reproduction. Environ Pollut 159:250-265

> Ruiz Y, Suárez P, Alonso A, Longo E, San Juan F (2013) Mutagenicity test using Vibrio harveyi in the assessment of water quality from mussel farms. Water Res 47: 2742-2756

Ruiz Y, Suárez P, Alonso A, Vidal A, San Juan F (2014) Histopathological alterations of the mantle of Mytilus galloprovincialis from the Ría of Vigo (NW Spain): effect of persistent chemicals? In: Sauvé G (ed) Molluscan Shellfish Safety, Chap 21. Springer, New York, NY, p 239-248

Sánchez-Mata A, Mora J (2000) A review of marine aquaculture in Spain: production, regulations and environmental monitoring. J Appl Ichthyol 16:209-213

> Schlautman MA, Yim S, Carraway ER, Lee JH, Herbert BR (2004) Testing a surface tension-based model to predict the salting out of polycyclic aromatic hydrocarbons in model environmental solutions. Water Res 38:3331-3339

> Sikora AE, Zielke R, Datta K, Maddock JR (2006) The Vibrio harveyi GTPase CgtAv is essential and is associated with the 50S ribosomal subunit. J Bacteriol 188:1205-1210

Singer MM, Aurand D, Bragin GE, Clark JR, Coelho GM, Sowby ML, Tjeerdema RS (2000) Standardization of the preparation and quantification of water-accommodated fractions of petroleum for toxicity testing. Mar Pollut Bull 40:1007-1016

Słoczynska K, Pekala E, Wajda A, Wegrzyn G, Marona H (2010) Evaluation of mutagenic and antimutagenic properties of some bioactive xanthone derivatives using Vibrio harveyi test. Lett Appl Microbiol 50:252-257

Soclo HH, Garrigues P, Ewald M (2000) Origin of polycyclic aromatic hydrocarbons (PAHs) in coastal marine sediments: case studies in Cotonou (Benin) and Aquitaine (France) areas. Mar Pollut Bull 40:387-396

Stegeman JJ (1981) Polynuclear aromatic hydrocarbons and their metabolism in the marine environment. In: Gelboin $\mathrm{H}$, Ts'o POP (eds) Polycyclic hydrocarbons and cancer, Vol 3. Academic Press, New York, NY, p 1-66

US Environmental Protection Agency (1993) Provisional guidance for quantitative risk assessment of polycyclic aromatic hydrocarbons. EPA/600/R-93/089. Environmental Criteria and Assessment Office, Office of Research 
and Development, Washington, DC

> Villeneuve DL, Khim JS, Kannan K, Giesy JP (2002) Relative potencies of individual polycyclic aromatic hydrocarbons to induce dioxinlike and estrogenic responses in three cell lines. Environ Toxicol 17:128-137

Wegrzyn G, Czyz A (2003) Detection of mutagenic pollution of natural environment using microbiological assays. J Appl Microbiol 95:1175-1181

WHO (World Health Organization) (1989) IARC Monographs, Vol 46. International Agency for Research on Cancer, Lyon p 41-155

WHO (World Health Organization) (1991) Evaluation of cer-

Editorial responsibility: Peter Cranford,

Dartmouth, Nova Scotia, Canada tain food and additives and contaminants. In: Thirthy seventh report of the Joint FAO/WHO Expert Committee on food additives. WHO Tech Rep Ser 806. WHO, Geneva, p 27-29

> Yunker MB, Backus SM, Graf Pannatier E, Jeffries DS, MacDonald RW (2002a) Sources and significance of alkane and PAH hydrocarbons in Canadian Arctic rivers. Estuar Coast Shelf Sci 55:1-31

Yunker MB, MacDonald RW, Vingarzan R, Mitchell RH, Goyette D, Sylvestre S (2002b) PAHs in the Fraser River basin: a critical appraisal of PAH ratios as indicators of PAH source and composition. Org Geochem 33:489-515

Submitted: July 16, 2014; Accepted: September 16, 2014 Proofs received from author(s): October 24, 2014 